\title{
Colonized by the Dark Whites Freed by Grace: An Analysis of the First Two Mizo Written Narratives
}

\author{
Lalnienga Bawitlung \& K.C. Lalthlamuani
}

\begin{abstract}
This paper attempts to study the colonial influence that destroyed the balance between the lives of Mizo men and women- the people who made their entry into the forested mountainous regions of Northeast India, later known as Mizoram in the late 17th centurythrough the narratives of L. Biakliana (1918-1941), author of the first Mizo novel Hawilopari (1936) and the first Mizo short story "Lali" (1937). The life of a Mizo woman was more burdensome in the last decade of the 19th century and first three decades of the 20th century than at any given point of time. The acuteness of their sufferings in the early 20th century under patriarchal society is clearly described in "Lali", wherein they are likened to slaves and commodities that can be bargained and sold. However, a very different picture is depicted in Hawilopari, where there does not seem to be any differentiation in terms of gender. Women felt secure under the men's guidance before the appearance of the white men, who, with better weapons ruled the land prohibiting raiding and head-hunting whereas they themselves practiced it. For a short time even the emergence of the Missionaries was a great pain to the men because they had to put away their paganistic ritualistic practices. Men who were not used to performing household chores were at a loss and could not cope with the new peaceful life as they were fresh from battlefields.
\end{abstract}

Keywords: Mizo, Dark Whites, Patriarchy, Colonial Influence, Christianity.

\section{Introduction}

According to historical accounts, Mizos were warlike clans even from the period of their stay in the west side of the Run river (or Manipur river) from the early 16th century to late 17th century (Liangkhaia, 2019, p. 55). Raiding and enslaving continued to be a part of their life with their increasing possession of firearms even after they crossed the Tiau river into India in the 18th century. The coming of more gunpowder after the Anglo-Burmese war in the "1820s" (Lalrimawia, 1995, p. 5) intensified the battle between villages. The raids persisted and escalated reaching its peak in the middle of the 19th century resulting in the men's continual involvement in war not only amongst the Mizo clans but against the British force as well.

During these three hundred fifty hard years, Mizo women's problems were always overshadowed by the men's engagement in raids and actions outside the house which demanded great physical energy. The appearance of the Colonizers during the second half of the 19th century deprived men of their gender roles whereas the responsibilities of the women remained the same destroying the balance of life which had been carried on for generations. It is no wonder the earliest Mizo written narratives written under the colonial influence were both named after Mizo female names- one after a pagan name and the other after a Christian 
name.

\subsection{The Balance}

From the moment the Mizo people made their entry into the forested mountainous regions of Northeast India, later known as Mizoram, in the late 17th and early 18th century, the period of the pasaltha ${ }^{1}$ continued till the last decade of the 19th century. Being a warlike clan, ferociousness was embedded in the blood of most of the Mizo men to face threats from wild beasts and their enemies. Since the majority of the men's lives involved raids and intervillage wars along with the willingness to sacrifice their lives, they were not only very much feared and held high by their women counterparts but were highly esteemed by the village chiefs or kings. The words of these hunter-warriors never passed unheeded before the chiefs and his councillors which, in fact, is the reason why Mizo pasalthas had better reception and recognition than the chief's councillors throughout Mizo history (Lalthangliana, 2016, p.159).

These hardened men shouldered the most difficult roles in society which demanded great physical exertion with courage and endurance, whereas their women were tasked mainly with household chores requiring milder effort. There was a distinct division of work between men and women, as the old Mizo saying goes "men rule at forge and women at spring-well" (Colney, 2017, p. 18). It used to be considered defamatory on the part of a man if he could not provide his wife $\mathrm{Em}^{2}, \mathrm{Hnam}^{3}$, Mauthei ${ }^{4}$ etc., and on the part of a woman it was shameful if she could not sufficiently weave and provide clothes for the family (Dokhuma, 2015). This clear-cut division of responsibility was the result of their awareness and consciousness of the physical and mental abilities as well as their shortcomings which upheld the balance of life in the society.

Life in the woodland hilly regions of the rugged remote rural areas was not very easy. The livelihood problems, especially of the women, were considerably heightened, because their work involved fetching water, feeding flocks, collecting firewood, grinding paddy, preparing meals for the family, etc., and men hardly got involved in all these household chores. The roads the women frequented to fetch water and firewood were the literal definitions of the ups and downs of life. However, both the sexes' acceptance, understanding and respect for each other's responsibilities were clearly felt as, for instance, when a man at inevitable circumstances went to the spring-well to fetch water even during summer when scarcity of water was at its peak, they would give way to let him scoop first even if the women had to wait till midnight. The men did the same when a woman went to forge, construing that the family man must be sick or out of station. In this patriarchal Mizo society, where, according to numerous accounts, women are never vested with substantial authority, there is a very paradoxical story. 'Pawngvina', a character in the story by the same name, is considered to be the worst-tempered man of all the Mizos but he was alleged to have always been afraid of his wife:

"I huaisen hle si a, engtizia nge i nupui hi I ngam miah loh mai hi le?" an tih pawhin, Pawngvina chuan, "A mak ngawt mai! a lakah thih ka hlau chu a ni hauh si lo," a ti a. (Lianthanga, 1999, p. 6)

(You are such a courageous man, why is it that you are afraid of your wife?" they asked. Pawngvina simply replied, "So strange it is! It's not even that I fear to die in her hands).

This balance of life, amidst its disbalancing, between men and women in the past Mizo society is depicted by L. Biakliana (1918-1941) in Hawilopari (1936), the first Mizo novel. Also, in "Lali (Lalawmpuii)" (1937) the first Mizo short story he delineates the aftermath of the destruction of the ancient way of living by the colonizers, with the introduction of a better way of life through the advent of the Christian Missionaries.

\subsection{Hawilopari}


The story of Hawilopari is set in the second half of the 19th century when raiding was still active in Mizoram. Although the author says in the first page of the novel that this story was set right after "the war of the East and the West" (1877-1880) had broken out (1936, p. 207), yet he seemed to have committed chronological error since the three main characters Hminga, Chhana and Liana who ran away ten years before are all depicted in their early twenties when they came back to Mizoram in 1871-1872 as British sepoys to bring back Mary Winchester ${ }^{5}$ (p. 244). The story was in fact set during the last stage and after "the war of the North and the South (1841-1848)" (Liangkhaia, 2018, p. 70) if historical elements in the novel were to be followed. The people in this story then were in the midst of turbulence sandwiched between the two greatest wars in Mizo history when havoc caused to the land by the Colonizers was at its height. The portrayal of the roles of Mizo men and women during this period was still in balance in a sense that they were used to raids and all the horrible sights that came along, and the hardships faced by women were no greater than those of the hunter-warriors. The equality of men and women is seen when Hawilopari's father said,

.... hmeltha deuh mai a ni ka neih dawn ni, ka fa hmasa ber chu mipa a nih leh Hawilopara, hmeichhia a nih leh Hawilopari. (p. 207)

(... I am going to have a very good-looking child, if my first-born is a boy, I will name him Hawilopara, and if a girl, Hawilopari).

According to ancient Mizo myth, when people die, the spirit of the dead on his way to pialral or paradise would be filled with longing for the world he has just left. There is this flower when plucked makes the spirit forget to look back for a glimpse of the past but goads him towards lunglo tui or water of forgetfulness in order to erase all the memories and yearning for which have been left behind. Hawilopar is the name of that flower of 'forgetfulness' and 'progress'. The father's propositional name for the coming child is symbolical of a progressive and beautiful future which will be ushered in for the parents by the child regardless of sex. He did not esteem a boy over a girl child, the idea of which is very prevalent in many parts of mainland India even to this day wherein a boy child is preferred over a girl child.

The idea of guardianship of the men for their family and women at that particular period of history was pronounced more and more in the parents' upbringing of Hawilopari especially, when it came to marriage, the most important phase of one's life. When she was proposed to by one of the village chief's counsellors' son, Khuala, her acceptance was taken into consideration by her parents against the general conception that a young woman never had her say during those days. Although she was pushed by the powerful suitor, she refused to consent to the marriage proposal since he was not the man of her liking (pp. 280-281). And when Hawilopari's family was threatened to banishment from the village, her father, after hearing all her accounts, consoled her thus:

Chuti a ni maw le, Parte le, i duh lohnaah zawng eng pawh ti rawh se, kan tawn zel ang. (p. 282)

(So, that's the matter, Parte (an endearment name), if you aren't willing to have him, we will always fight for you regardless of their actions).

Traditionally, a Mizo man had to work very hard in order to have a good wife since he had to give a large sum of money, goods or livestock to compensate a woman's absence from her parent's household, the tradition of which was in contrast with the practice of demanding dowry as in the context of many parts of mainland India. In the above extract, the father made it very clear that her daughter was not to be bought or sold even if the suitor had the capacity to enrich them.

Despite the fact that the work is an expression of the sympathetic attitude of the author towards the plight of the Mizo women of the past, he nonetheless does not neglect the heavy burden of the Mizo men who were fearless of their rulers when it came to safeguarding their integrity. These courageous men were reverently called by the chiefs the 'dai ngul' 
('pillars of fencing wall') of the village who upheld the honour of the chiefdoms. Hawilopari's father represents the spirit of warriorship that had been inculcated for generations in the lives of the men; and the democratic nature of the village administration under an autocratic ruler where the departure of brave men like him from the village could be followed by others, eventually making the chief a "despot without subjects." (Dokhuma, 2015, p.145)

Chapter six of the novel relates how the period of the pasaltha was about to be over when the male protagonist of the story Hminga and his three friends, one of whom was the son of a village chief, served the Britishers as their sepoys. The subalterness of the Mizo men is confirmed in the ninth chapter. In this chapter, Hminga, who had been serving the Whites for some years with excellent records one day inquired why he had not been included amongst the soldiers selected for the coming expedition. He was bold enough as the British officer had been good to him for the services rendered. But he was taken aback and felt that his being was diminutised by the reaction he received from the officer who without looking at him shouted:

Kal bo rawh, min rawn ti buai suh.... Rang takin kal bo rawh. (p. 252)

(Get away, do not disturb me.... Get away quickly).

The officer as later narrated had had an argument with another officer for reasons unknown to other characters or the readers hinting at the secretiveness of the Britishers. His impenetrable spirit of the darkness of his heart was poured upon an innocent man who had nothing to do with his affairs.

\section{The Colonizers}

The expedition the novelist talked about was what the Colonizers called 'the Lushai expedition of 1871-1872'. In the campaign, the Left or Cachar Column was led by Brig. General G. Bouchier, and the 'Right or Chittagong Column was under the leadership of Brig. General G.A. Brown Low (Lalthangliana, 2016, pp. 166-170). Their purpose of taking back Mary Winchester looked insignificant considering their actions of burning down numerous villages on their way, it was more like a show of their prowess. This campaign along with 'The Expedition of 1889' under the guidance of Colonel F.V.C. Tregar ravaged Mizoram severely and completely ended the reign of the Mizo Chiefs who had not had for 200 years any other foreigners or tribes above them in this land. Their actions were a follow-up of Colonel Lyster's words- the man who had burnt down Sentlang village and killed many villagers in 1850 (2016, p. 162). The ominously threatening words ran thus: “... this robber tribe will not cease to infest the frontier until they shall have been severely dealt with." (Low, 1883, p. 110)

According to the account of the Colonizers the inhabitants of the Lushai Hills, the Mizos, were "nothing but vicious marauders and headhunters" (Remruatkimi, 2016, p. 85). It was true that they were raiders who went out for killing expeditions to their neighbouring as well as far flung remote villages or even to the Plains beyond the Lushai Hills. But the colonial view of the actions of the men of Mizoram as unhuman-like, whose sole purpose of the raids was "to obtain skulls with which to adorn the graves of their ancestors" (p. 84) or for the decorations of their houses is indeed limited. Their purpose was even nobler than the so-called Colonizers' in that they raided other villages to protect themselves and their villages or to take vengeance without pretending to befriend them, whereas, the Imperialists first pretended to cooperate with all their dramatic amiability with the foreigners and then raided in order to enslave the inhabitants, colonize the land and more importantly to enrich themselves and their native land. It is not, hence, possible to rely on each and everything they said and recorded, even regarding the gender issues, though we must acknowledge certain truths and facts in their accounts. 
The courage and determination of the Mizo men were no match for the advanced weaponry held by the Colonizers which eventually ended the period of the pasaltha. Their broader knowledge of the world, greater sense of administrative skills and military strength to back them up supplanted the rule of the Mizo chiefs whose laws were an end to everything within his jurisdiction including the matter of sentencing a villager to death. They were deposed from the height of their mighty position, the status of which was often referred by their subjects and themselves as "ni leh thla kara leng" ("dwelling between the sun and the moon"). (Lalthangliana, 2016, p. 177) The conquest resulted in the inhabitants of the land being heavily fined and the position of Chieftainship reduced to that of a tax collector. Though the indigenous raids were abolished, the foreign conquerors unabashedly used the Mizo men to take up arms for them against their will. The 'imposed labour' upon the men was so harsh that some of them expressed thus:

... Min tirethei reng reng atan an lo awm... engkim min thawhtir a, a hrehawm apiang min tihtir a, a tawpah phei chuan min la tihlum vek dawn a nih hi.... (p. 204)

(... Their existence is but to inflict us... making us work everything, they task us with the hardest of works, seems like they will slaughter us all in the end...).

The men who used to roam the Lushai hills as tigers for years were then used as horses and dogs but the women's business did not change much.

\section{The Christian Missionaries}

Unlike the Colonizers who wrecked pain and misery, the Christian Missionaries taught and freed the enslaved physically and spiritually. Upon setting foot on the land, the Missionaries prepared the Mizo "a aw b" ("alphabets") and started teaching from 1st April, 1894 (p. 220). The Missionaries' stance on slavery was in contrast with that of the colonial officers, for instance, the Mizoram Superintendent H.W.G. Cole restricted the movement of Dr. Fraser, a Christian Missionary, because of his interference in the matter. The Superintendent did not care for the soul of the indigenous people. Although, slavery had already been abolished in his own country in 1807, he did not then mind it being continued in Mizoram even a hundred years later during his superintendency from 1907 to 1911 (pp. 206-207).

On another plane, by the time the Christian Missionaries entered Mizoram in "1894" (2016, p.219) the inter-village wars had relatively subsided and most of the information they chewed were from the earlier Colonizers' accounts. This limited their judgement of the gender role in Mizoram. They did not see the actual role of the Mizo men, their struggle and sacrifices to safeguard their family, villages and the area they occupied letting them to emphasize the burdens and sufferings of the women without giving much heed to the importance of the historical context. They believed that the hardships faced by the women were only those of dependency of male on their female counterparts in doing the household chores; their lack of power in the decision making of the family involving inheritance, divorce and marriage were all too much.

For these reasons, the Christian Missionaries E.M., Chapman, M. Clark and M. Sykes in their co-authored book the Mizo Miracle (1968) states that the Mizo female, from the moment of their birth, do not enjoy their freedom and that their body, mind and soul belonged to their fathers, brothers and husbands (p. 12). Lakfakzuali's statement is very significant for the early 20th century Mizo men and women's domestic life:

"In the early Mizo home, as often stated, the men kept themselves aloof from doing even a single household work for dislike of being called a henpecked husband and laughed at by fellowmen and community." (2010, p. 20)

This is the exact view of the Christian Missionaries and the earlier writers whose minds were colonized to a great extent.

The regulations enforced upon the Mizo people were so bitter that it can be compared to the bitterness of 'Quinine'. The abolishment of their pagan ritualistic practices mainly performed by men and the prohibition of alcoholic drinks amongst new converted Christians 
were very difficult to swallow. Whereas for the women no adjustment was needed since they hardly drank intoxicating drinks.

\subsection{The Imbalance}

The disappearance of their main engagements in quick succession with their conversion to Christianity confounded the Mizo men, engendering their inability to adapt to the new conditions of life which was very different from the practices they had carried on for several generations. With their inclination towards fighting battles and confrontations with wild beasts, it was very difficult for them to live such a peaceful life brought about by the Christian Missionaries in a very short span of time. Shorn off their previous responsibilities, what remained was them becoming responsible and caring men helping their women in the household chores which they had not performed for centuries because of the ancient clear-cut division of responsibilities. Whereas for the women, the life they used to lead, without difficulties or much changes, conformed with the normal Christian life. This situation put the men in a very bad light.

\section{2. "Lali"}

Written in the year 1937, fifty-four years after the advent of the Christian Gospel in Mizoram, "Lali" mainly deals with the conditions of the early Mizo Christian women. The story is set three to four decades after Hawilopari when the majority of the people of the land were already Christianized. The experience of the terror caused by wild beasts had gone relatively fewer in numbers with their increasing possessions of better weapons; the superstitious beliefs and rituals performed by the men had been altogether diminished; and more importantly people no longer engaged in raids and wars which had been the main concern of the Mizo men. It was the period when the men still retained the heart of a warrior, when in fact, they were servants who had not come to the realization that the balance in the society had been destroyed. Although being servants they still expected to be treated like masters by their women which they had always been enjoying until the appearance of the Britishers resultantly hurting them both.

Pitting himself in the shoes of Mizo women, Biakliana's understanding of the plight of Mizo women seems more insightful than any other writers in that his short story. "Lali (Lalawmpuii)" won him the "Lawmman pakhatna" ("First Prize") in the first ever short story writing competition held in Mizoram which was themed "Mizo hmeichhe chan" ("the lot of Mizo women") in order to bring consciousness about the life of the contemporary Mizo women (Khiangte, 1996, p. 31). The plight of the early 20th century Mizo women Is clearly stated in his story:

An chan hrehawmzia leh awl lai an neih lohzia leh hmeichhiate reng reng chan hrehawmzia ngaihtuah zawm ta zel ni awm tak hian, ngawi rengin an kal ta a. (p. 178) (They went on quietly as if pursuing their thoughts of the hardships of their lot, their hectic life and the hardships of all the other women in their position).

Lali, the main character who is the representative of the Mizo women of her day, spoke to her mother in the very first line of the short story of the urgent need for fetching water when she says,

Ka nu, tui chawi a tul hle si a.... (p. 177)

(Mother, as it is very much needed to fetch water...).

Except for the rainy season, they always had to fetch water from the spring-well which was a good long distance away. Fetching water during summer and winter was one of the main burdens of women because there usually was shortage of water during these seasons in the majority of the places and the women had to struggle to supply the demands of the family. The need for water was increasing as the people were more conscious of the benefit of cleanliness but men were still reluctant to help them. 
The climactic descriptions of the life of the Mizo women in respect to relationship and marriage is reached when the writer deals with the issues of marriage. For the "sapte,"5 according to L. Biakliana, it is the most beautiful moment, the coming of which is eagerly awaited (p. 188). But for some, like the Mizo women, who do not have any say in choosing their partners it can turn out to be a dreadful and harrowing experience:

... Mizo hmeichhia, kan farnute tam tak tan chuan hetiang hun lo thleng hi thil huphurhawm ber mai, mittui tla leh lungchhe chunga hman a ni fo thin. (ibid.)

(... For Mizo women, many of our sisters, the coming of this occasion is the most dreadful moment, often spent with tears and broken hearts).

As is shown in the story, the parents of Lali had rejected some suitors because they knew that they would not be able to meet the monetary amount to be demanded by them for the bride's prize. The procedure of marriage is likened by the writer to the selling and bargaining process of material goods:

Bungrua ang maiin kan hralh a, kan innep a.... (ibid.)

(We sell them like goods, we even bargain for them...).

Unlike Hawilopari in Hawilopari, Lali's parents did not ask the young lady if she was willing when suitors approached them. But they rushed and pushed their daughter when the suitor seemed to be able to fulfil the parents' desire. This was painful and detrimental for her. In the case of the short story, the parents did not even bother to ask the deeper character of the man whether he would be a compatible partner for their daughter or not. They were impressed by his outward appearance, his family's financial possession and social standing. Only after the decision was made and concluded did they inform their daughter. Only for the sake of formality did they reason, consult and debate with their daughter when the winner was already predetermined and the victim had no other choice but to comply. All her will, longing, personal desire and choices are trampled and ignored.

Such circumstances are the ones the Christian missionaries emphasized to a great extent, because when the women are not allowed to choose their lifetime partners, the parents are forcingly snatching their birth right. The practice of marrying off one's daughter even against her will must have been, comparatively, abundant during the early 19th century, as from the account of L. Biakliana.

Tunlai kan ram hmeichhiate pawh hi chutiang chuan kan enkawl vek ti ila, a dik kher lo a nih pawh a ni thei e; eng pawh ni se, a tam zawk chu an ni. (p. 188)

(It might not be correct to say that, these days, we still treat all of our women in that manner; but the majority of them are treated that way).

The treatment meted out to the women, especially by the parents in the story, is compared to the treatment of animals and commodities over which the possessor has full control, therefore, the women are referred to as "salte" (slaves) as they work very hard day and night without outwardly daring to question their predicament, confiding their inner suffering only to their closest friends or their mothers without any effect:

Lali leh Thani chuan an sawi dun thin a, an sawi rei tawlh tawlh leh a pik deuh deuh mai hian an hria a, an mangan tawpah an tawngtai thin a, chuti chung pawhin a la veng thei lo. (p. 189).

(Lali and Thani often talked about it, the longer they discussed the more complicated they felt of the situation, they'd pray when they could no longer console themselves, still, they were scarcely lightened).

The struggle between paganism and Christianity is depicted in the picture of Lali's father, a disbeliever and drunkard and that of Lali and her father after conversion respectively. Lali's father is representative of the Mizo men of his time who were still influenced by past generations. A man who felt very lost and isolated in contemporary society, whose drunkenness and continual idling was a sign that he had been divested of his former responsibilities and could not quite cope with the present way of life. His later 
conversion and his daughter's marriage according to her will with her chosen man showed the transitioning and turning of a new page in the history of Mizoram.

\title{
Conclusion
}

It was unlikely that the Mizo women would always complain about their share of responsibilities knowing that the responsibilities were equally divided according to one's ability and that men were not idling around but always putting their hands on the harder part of the work. Moreover, their readiness to sacrifice their life for their women is beyond question throughout Mizo history, it was the men who used to stand before wild beasts and enemies. Unless the Mizo men's intention of protection, their sense of compassion and love are interpreted incorrectly it would be difficult for one to say that they are treading on their women and treat them badly like "slaves". Whereas in fact,

$\ldots$ in the Mizo society, the $b a w i^{6}$ or $s a l^{7}$ children grew up in the captor's house as his own children and as a rule they were so well treated that they seldom wished to return to their former house. (Remruatkimi, 2014, p. 85)

Early 20th century was a very harsh period for the Mizo woman, however, as it is said that 'the hour just before the dawn is the darkest,' so was their life. Men gradually adjusted and the golden period in Mizo history dawned a few years after the composition of this story. Only a few generations after the transition occurred, the gender gap is in the process of narrowing down and the balance in the society is being restored day by day.

\author{
Notes \\ ${ }^{1}$ hunter-warrior. \\ ${ }^{2}$ woven-basket. \\ ${ }^{3}$ plaited band of cane with attached ropes, used to support a load when carried on the back. \\ (Vanlalngheta, 2020, p. 176) \\ ${ }^{4}$ bamboo vessels used for collecting and storing water. \\ ${ }^{5}$ an illegitimate daughter of a Scottish man James Winchester and his Meitei worker. Silliam \\ village chief Bengkhuaia's men killed her father and she was captured and brought to \\ Mizoram as a hostage in 1871 and rescued by the Britishers in 1872. \\ $6 \& 7$ slaves.
}

\section{References}

Biakliana, L (1936). Hawilopari. In Laltluangliana Khiangte. (1996). Biakliana Robawm, pp. 205-359, (7th ed.). L.T.L Publication.

Biakliana, L. (1937). Lali (Lalawmpuii). In Laltluangliana Khiangte. (1996) Biakliana Robawm, pp. 175-203, (7th ed.). L.T.L Publication.

Chapman, E.M., \& Clark, M. (1968). Mizo Miracles. Ed. Majorie Sykes. Madras Christian Literature Society.

Colney, Rualkhuma. (2017). Hmanlai Mizo nuna mipa leh hmeichhiate dinhmun bih chianna. Ram Dan leh Hmeichhiate, Rualkhuma Colney. Government Law College. 
Dokhuma, James. (2015). Hmanlai Mizo Kalphung (5th ed.). Gilzom Offset.

Khiangte, Laltluangliana. (1996). Biakliana Robawm (7th ed.). L.T.L Publication.

Lalrimawia. (1995). Mizoram-History and Cultural Identity (1890-1947). Krishna Kumar Spectrum Publication.

Lalthangliana, B. (2016). Mizo Chanchin (A Short Account of Mizo History) (2nd ed.).

Gilzom Offset.

Liangkhaia, Rev. (2019). Mizo Chanchin (History of the Mizos) (6th ed.). L.T.L.

Publications.

Liangkhaia, Rev. (2018). Mizo Awmdan Hlui (3rd ed.). L.T.L. Publications.

Lianthanga, C. Hmanlai Mizo Nun. Mizoram Publication Board, 1999.

Low, Charles Rathbone. (1883). Major-General Sir Frederick S. Roberts, Bart., V. C., G. C. B., C. I. E., R. A., A Memoir. London: W. H. Allen.

Remruatkimi. (2014). Colonial accounts of the Mizo. Mizo Narratives: Accounts from Mizoram. R.K. Pillai for Scientific Book Centre, pp. 83-91.

Siama, V.L. (1953). Mizo History (2019 ed.). Lengchhawn Offset.

Vanlalngheta, J.T. (2020). The BritAm Mizo - English Dictionary (4th ed.). J.T.

Vanlalngheta. 
Colonized by the Dark Whites Freed by Grace: An Analysis of the First Two Mizo Written Narratives

\section{$\underline{\text { Bio-Note }}$}

Lalnienga Bawitlung is a Research Scholar pursuing M.Phil. in the Department of English, Mizoram University.

E-mail: lalnienganite@gmail.com

K.C. Lalthlamuani is a Professor and currently the Head, Department of English, Mizoram University.

E-mail: kayz1511@gmail.com 